\title{
Önceki Kayıpların Neden Olduğu Negatif Ruh Halinin Hisse Senedi Talebine Etkisi
}

\author{
İbrahim BOZKURT*
}

\section{ÖZET}

$\mathrm{Bu}$ çalışmanın temel amacı, negatif ruh halinin yerli ve yabancı yatırımcı davranışları üzerindeki etkisini incelemektir. Çalışmada negatif ruh hali önceki gün yaşanan kayıplar ile temsil edilmektedir. Bilinmektedir ki önceki gün kayıp yaşayan yatırımcıların bugünkü ruh hali negatiftir. Çalışmada, Kasım 2005 - Nisan 2015 dönemi aralığında yerli ve yabancı yatırımcıların portföylerinde bulunan günlük hisse miktarları ile bu portföylerin Pazar değerleri, veri olarak kullanılmaktadır. Çalışmanın analizleri, Newey-West tahmincili OLS regresyon analizi kullanılarak gerçekleştirilmiştir. Çalışma sonucunda; negatif ruh haline sahip yerli yatırımcıların hisse taleplerini artırdı̆̆ hisse taleplerini azalttığı tespit edilmiştir. Fakat öncesinde yaşanan kaybın sonraki günde telafi edilme olasılığı arttıkça yabancı yatırımcıların hisse taleplerini artırdı̆̆ı da ortaya konulmuştur.

Anahtar Kelimeler: Önceki Kayıp; Negatif Ruh Hali; Yerli Yatırımcl; Yabancı Yatırımcı; Yatırımcı Davranışı.

JEL Sinıflandırması: A12; G02; G11.

\section{The Effect of Negative Mood Caused By Prior Loses On the Demand for Stock}

\section{ABSTRACT}

The main purpose of this study is to investigate the effect of negative mood on domestic and foreign investors' behaviour. In this study, negative mood is represented by prior loses. As is known, in today's mood of investors who have losses in the previous day is negative. In this study, stock numbers in the portfolios of domestic and foreign investors and market values of these portfolios between November 2015 and April 2015 are used as data. Analyses are performed by OLS regression analysis with Newey-West estimator. The results of this study reveal that domestic investors with negative mood increase their stock demands instead of decreasing it the way foreign investors do. However, if the probability of making up for the prior losses increases on the next day, foreign investors also raise their stock demands.

Keywords: Prior Loses; Negative Mood; Domestic Investor; Foreign Investor; Investor Behaviour.

Jel Classification: A12; G02; G11.

\footnotetext{
* Yrd. Doç. Dr. İbrahim Bozkurt, Çankırı Karatekin Üniversitesi, İİBF, Bankacılık ve Finans Bölümü ibozkurt@karatekin.edu.tr
} 


\section{GíRiş̧}

Finans bilimine göre rasyonel yatırımcı, duygusu olmayan bir varlıktır ve o, elindeki tüm bilgiler 1şığında faydasını maksimize etmeye çalışır. Belirsizlik altında yapılacak riskli bir varlık yatırımından beklenen fayda; o yatırımdan beklenen muhtemel tüm sonuçların, ilgili sonuçların objektif olasılıklarıyla ağırlıklandırılmış bir fonksiyonudur. Ne var ki bir yatırımın muhtemel tüm sonuçlarının objektif olasılıkları, esasında sübjektif olarak belirlenir. Loewenstein (2000), Romer (2000) ve Loewenstein vd. (2001), olasılık ağırlıklı bu fonksiyonun sonucunun, yatırımcının ruhsal durumuna göre değişim gösterebileceğine dikkat çekmektedir; yani riskli varlık yatırımlarından beklenen faydalar dolayısıyla bu faydaları temel alarak verilecek kararlar, yatırımcıların ruhsal durumundan etkilenebilir.

Ruh halinin $\left(\operatorname{mood}^{1}\right)$ karar alma süreci üzerindeki etkisi, hem laboratuvar ortamlarında hem de alan çalışmalarında sıklıkla incelenmektedir. Laboratuvar ortamında yapılan ve psikoloji literatüründe yer bulan çalışmaların hemen hepsi; karar alma sürecindeki en temel belirleyici unsurun ruh hali olduğunu ve ruh halinin finansal kararların alınmasında belirleyici olan risk algısı ya da risk toleransı gibi birçok faktöre etki ettiğini ortaya koymaktadır. (Bower, 1981; Johnson ve Tversky, 1983; Isen vd., 1978; Schwarz ve Clore, 1983; Schwarz ve Clore, 1988; Wright ve Bower, 1992). Laboratuvar deneylerinde olduğu gibi alan çalışmalarıyla yapılan ve davranışsal finans literatüründe yer bulan çalışmalarda da açığa çıkarılan husus; ruh halinin, bireyin risk algısına ve riskli varlıklara yönelik taleplerine doğrudan tesir ettiğidir (bakınız, literatür taraması).

Laboratuvar deneylerinde, bireylerin ruh hali ile riskli varlıklara yönelik talepleri arasındaki ilişkinin tespit edilmesi amacıyla deneklerin ruhsal durumu, onlara kısa video klipler izletilerek, müzikler dinletilerek, kısa hikâyeler okutularak, küçük hediyeler verilerek ve bunlara benzer eylemler yaptırılarak pozitif ya da negatif yönde değiştirilmektedir. Davranışsal finans alanında yapılan çalışmalarda ise ruh hali, bireylerin ruhsal durumlarını değiştirebildiği varsayılan bir takım faktörler (hava sıcaklığı, mevsimler ve dolunay gibi) ile temsil edilmekte ve bu faktörler, ruh halinin vekil değişkenleri olarak analizlerdeki yerini almaktadır (bakınız, litaratür taraması). Thaler ve Johnson'a (1990) göre, daha öncesinde yaşanan kayıplar (prior losses), bireylerin ruh halini negatif yönde değiştirmektedir; yani önceki gün kayıp yaşayan birinin bugünkü ruh hali, negatiftir. Bu doğrultuda bu makalede de önceki gün borsada yaşanan kayıplar, negatif ruh halinin vekil değişkeni olarak kullanılmaktadır.

\footnotetext{
${ }^{1}$ Psikologlar uzmanlık alanları gereği "affect", "mood” ve "emotion" gibi kavramlar arasında bir ayrım yaparlar; fakat davranışsal finans literatüründe ise bu kavramlar sıklıkla birbirlerinin yerlerine kullanılır (Lepori, 2010). $\mathrm{Bu}$ çalışmada da bu geleneğe uyulmaktadır.
} 
$\mathrm{Bu}$ çalışmanın temel amacı; negatif ruh halinin (önceki günde yaşanan kayıpların), Borsa İstanbul (BİST)'da işlem yapan yatırımcıların hisse senedi alım satım davranışları (talepleri) üzerindeki etkisini analiz etmektir.

$\mathrm{Bu}$ makale; (i) negatif ruh hali ile yatırımcıların hisse senetlerine yönelik talepleri arasındaki ilişkiyi, yerel literatürde ilk kez, önceki günde borsada yaşanan kayıpları temel almak suretiyle ölçerek ve (ii) negatif ruh halinin yatırımcıların hisse alım-satım davranışlarına olan etkisini, yerli ve yabancı yatırımcı özelinde ayrı ayrı analize tabi tutarak literatüre katkı sağlamaktadır. Makalenin literatüre sağladığı üçüncü bir katkı da; negatif ruh halinin salt yerli yatırımcıların hisse talep miktarlarında daha fazla artışa neden olduğunu, sonuç olarak ortaya koymasıdır. Çalışmada ulaşılan ilginç ve şaşırtıcı olan bu sonuç, robust olup; psikoloji alanında yapılan az sayıdaki çalışma sonucu ile örtüşmekte, fakat davranışsal finans alanında yapılan çokça çalışmanın sonuçları ile örtüşmemektedir. Bunun nedeni, yerli ve yabancı yatırımcılar arasındaki kültürel farklılıklar olabilir.

\section{LITERATÜR TARAMASI}

\subsection{Negatif Ruh Halinin Riskli Varlıklara Yönelik Talep Üzerindeki Etkisi}

Karar alıcı, karar verme sürecinin her aşamasında kendi ruh halinin tesiri altındadır (Loewenstein vd., 2001). Bower (1981), Johnson ve Tversky (1983), Isen vd. (1978), Kavanagh ve Bower (1985) ile Wright ve Bower'in (1992) çalışmalarına göre, bireyin içinde bulunduğu ruh hali, onun karar verme sürecindeki nihai yargısını aynı yönde etkilemektedir. Yani negatif ruh haline sahip bir birey, pozitif ruh haline sahip olan bir bireye nazaran, alacağ kararlarda daha kötümser olmaktadır. Bu durum, duygu durum tutarlığı ( $\operatorname{mood}$ congruency) etkisi ile açıklanabilir. Duygu durum tutarlığı, bireyin düşüncesi ile onun ruh hali arasındaki eşleşmeyi ifade eder (Myer vd., 1992). Duygu durum tutarlığı etkisine göre, bireyin düşüncesi, onun ruh haline ayak uydurur; yani yatırımcı kendini ruhsal olarak kötü hissediyor ise aklına sürekli kötü düşünceler ya da korkular gelir (zarar etme korkusu gibi) ve bu nedenle de riskten kaçınır (yani kişinin risk algısı artar ve riski tolere etme isteği azalır). "Affect as information" teorisi de bireyin ruh hali ile vereceği kararlar (ya da bireyin risk algıs1) arasındaki ilişkiyi açıklayabilir. Bu teoriye göre; bireyler, bir karar almadan önce, genel olarak, karşı karşıya oldukları durum hakkında kendi kendilerine "bunun hakkında ne hissediyorum?" ya da "nasıl hissediyorum?" sorularını sorarak bir değerlendirme yaparlar ve bu değerlendirme sonucuna çoğunlukla onların ruh halleri etki eder (Schwarz ve Clore, 1983, 1988). Yani negatif ruh haline sahip bir birey, pozitif ruh haline sahip olan bir bireye nazaran alacağı kararlarda daha kötümser olur; risk algısı artar. Örneğin Yuen ve Lee (2003); video klipleri izleterek neşelerini kaçırdıkları deneklerde, risk alma eğiliminin azaldığını tecrübe etmişlerdir. 
Birinci grupta toplanan bu görüşlerden çıkarılan nihai sonuç; negatif ruh halindeki bireylerin risk algılarının artacağı ve daha fazla riskten kaçınma eğiliminde olacaklarıdır. Daha fazla riskten kaçınma eğilimi de riskli varlıklara (burada hisse senetlerine) olan talepleri azaltacaktır.

Araştırmaların büyük bir kısmı, pozitif (negatif) ruh halinin risk alma eğilimini artıracağı (azaltacağı) beklentisini güçlü kanıtlarla desteklemektedir (Yuen ve Lee, 2003). Az sayıdaki araştırma ise ruh hali ile risk alma eğilimini arasındaki pozitif ilişkiyi kısmen ya da tamamen reddeden ve bu ilişskinin negatif yönde olduğunu ortaya koyan bulgulara sahiptir. Bir çalışma, hüzünlü katılımcıların daha yüksek risk alma eğiliminde olduklarını göstermektedir (Raghunathan ve Pham, 1999). Bruyneel vd. (2009) de negatif ruh haline sahip bireylerin riskli varlıklara yöneldiğini açığa vurmaktadırlar. Leith ve Baumeister'e (1996) göre, negatif ruh halindeki insanlar, emniyetli seçeneklere nazaran riskli seçenekleri tercih etme eğilimindedirler. Lin vd. (2007); karar anında kendini üzgün hisseden insanların, risk almakta daha istekli olduklarına ve kazanç sağlama potansiyeli daha fazla olan seçenekleri tercih ettiklerine dair kanıtlar sunmaktadırlar. Conte vd. (2013) de üzüntü, kızgınlık ve korku durumlarının, bireyleri riskli davranışlara yönelttiğine işaret etmektedirler.

İkinci grupta toplanan bu görüşlerden çıkarılan sonuç ise negatif ruh halindeki bireylerin daha fazla risk alma eğiliminde olacaklarıdır. Daha fazla risk alma eğilimi de riskli varlıklara (hisse senetlerine) olan talepleri artıracaktır.

Negatif ruh halindeki bireylerin daha yüksek risk almaya gönüllü olmalarının nedeni; daha yüksek kazançlar sağlamak suretiyle negatif duygularını onarma umuduna sahip olmalarıdır (Mittal ve Ross, 1998). Mick ve Demoss'a (1990) göre kendilerini depresif hisseden negatif ruh haline sahip kişiler, kendilerine hediye alma eğilimindedirler; yani negatif ruh haline sahip bireyler, yaşanan olumsuzlukların ödül ile ikame edilmesini istemektedirler. Zillmann (1988); negatif ruh halindeki bireylerin, ruhsal durumlarını düzeltmek için yüksek riskli (yüksek getirili) tercihlere yöneleceklerini ileri sürmektedir. Değinilen hususlar göstermektedir ki negatif ruh halindeki bireyler, "duygu durumunun düzeltilmesi- mood repair” güdüsü ile hareket etmektedirler (Isen ve Geva, 1987). Durumu özetler nitelikteki bilgileri sunan Thaler ve Johnson (1990) da negatif ruh haline sahip kişilerin (yani daha öncesinde kayıplar yaşamış kişilerin), zararlarını telafi etme fırsatını veren riskli tercihleri daha çekici bulduklarını ortaya koymuştur (break-even effects).

İkinci görüşten ince bir farkla ayrılan üçüncü görüşe göre de; negatif ruh halindeki bireylerin, zararlarını telafi etme olasılıkları arttığı sürece daha fazla risk alma eğiliminde olacaklarıdır. Risk alma eğiliminin, zararların telafi edilme olasılığının artması şartıyla artacak olması, yine riskli varlıklara (hisse senetlerine) olan talepleri artıracaktır

Dile getirilen hususlar doğrultusunda, bu çalışmanın üç farklı hipotezi bulunmaktadır:

$\mathbf{H}_{1 \mathbf{a}}$ : Önceki kayıpların arttı̆̆ı yani yatırımcı üzerinde negatif ruh halinin egemen olduğu dönemlerde riskli varlıklara (burada hisse senetlerine) olan net talep azalır. 
$\mathbf{H}_{1 \mathrm{~b}}$ : Önceki kayıpların arttı̆̆ yani yatırımcı üzerinde negatif ruh halinin egemen olduğu dönemlerde riskli varlıklara (burada hisse senetlerine) olan net talep artar.

$\mathbf{H}_{1 \mathbf{c}}$ : Önceki kayıpların arttığı yani yatırımcı üzerinde negatif ruh halinin egemen olduğu dönemlerde, kaybın telafi edilme olasılığı arttıkça riskli varlıklara (burada hisse senetlerine) olan net talep artar.

\subsection{Davranışsal Finans Alanında Yer Bulan Çalışmalar}

Davranışsal finans literatüründe; psikoloji biliminin yukarıda belirtilen görüşlerini temel alan ve yatırımcının ruh hali ile riskli bir varlık olan hisse senetlerine yönelik talepleri arasındaki ilişkiyi incelemek amacıyla yapılmış olan birçok çalışma bulunmaktadır. Bu çalışmaların tamamında, iyi ya da kötü ruh hali, ruh haline etki eden faktörler ile temsil edilmektedir. Saunders (1993); yatırımcı ruh halinin, yatırım kararlarını (dolayısıyla da menkul kıymet fiyatlarını) etkilediğini buna karşın hava durumundan da etkilendiğini belirterek, New York şehrinin hava durumu ile New York borsası hisse senedi endeksi arasındaki ilişkiyi incelemektedirler. Bozkurt (2015); Dolunay’ın insan psikolojisi üzerindeki olumsuz etkisine değinmekte ve Dolunay'1, olumsuz ruh halinin vekil değişkeni olarak kullanmaktadır. Bulgulara göre; Dolunay zamanlarında, hisse talepleri ve doğal olarak da fiyatları azalmaktadır. Berument ve Ceylan (2012); futbol maçlarına ilişkin sonuçların bireylerin ruh hallerini etkilediğini belirterek futbol maç sonuçlarını, ruh halinin vekil değişkeni olarak kullanmaktadırlar. Futbol maçlarındaki mağlubiyetler (negatif ruh halleri), yatırımcının risk algısını artırmakta, hisse senetlerine olan talebi azaltmakta ve hisse fiyatlarını düşürmektedir. Hirshleifer ve Shumway (2003); güneşli havanın, iyimser ruh halinin nedeni olduğundan söz etmektedir. Güneşli günlerin, ruh halinin vekil değişkeni olarak kabul edildiği bu çalışma; gün 1şı̆̆ı ile hisse fiyatları arasında istatistiksel olarak anlamlı ve pozitif bir korelasyon ilişkisini doğrulamaktadır. Levy ve Yagil (2011); hava kirliliğinin ruh halini olumsuz yönde etkilediğini belirtmekte ve hava kirliliğini, negatif ruh halinin vekil değişkeni olarak kullanmaktadırlar. Onlara göre; hava kirliliği ile hisse getirileri arasında negatif yönlü bir ilişki mevcuttur (yani negatif ruh hali, hisse senetlerine olan talebi azaltmaktadır). Cao ve Wei (2005)'ye göre; hava sıcaklığı, ruh halini ve insan davranışlarını etkiler ve bu nedenle de sıcaklık, ruh halinin vekil değişkeni olarak kullanılabilir. Sıcaklık ile hisse getirileri arasında negatif ilişki tespit eden yazarlar, bu ilişkiyi, yaz aylarının miskin ruh haline neden olması ile açıklamaktadırlar. Son bir örnek olarak Białkowski vd. (2012) de; ramazan ayında Müslümanların pozitif ruh haline sahip olduklarını iddia etmekte ve çalışmalarında pozitif ruh halinin vekil değişkeni olarak ramazan ayını kullanmaktadırlar. Onlara göre; Ramazan ayındaki hisse getirileri, diğer aylardan istatistiksel açıdan anlamlı bir şekilde daha yüksektir.

Literatürde yer bulan bu ve benzeri çalışmalar, 2 temel ortak özelliğe sahiptir. Birincisi; ilgili çalışmaların tamamında, ruh halini etkilediği düşünülen olaylar ya da 
durumlar, ruh halini temsil eden vekil değişkenler olarak kullanılmıştır. Benzer şekilde bu çalışmada da önceki gün kayıp yaşanması, negatif ruh halinin vekil değişkeni olarak kabul edilmektedir. İkincisi ise; çalışmaların hemen hepsinde, negatif (pozitif) ruh halinin yatırım kararları ve sonuçta hisse talepleri üzerinde negatif (pozitif) etkisi olacağını savunan psikoloji temelli görüşleri destekleyen sonuçlara ulaşmışlardır. Bu çalışmanın yerli yatırımcılarla ilgili olan kısımları ise sözü edilen sonuçlarla örtüşmeyen bulgulara sahiptir.

\section{VERILLER}

Yatırımcıların, t-1 gününde kayıp yaşayıp yaşamadığ Denklem 1 ile; $t$ gününde hisse senetlerine yönelik taleplerinde artış olup olmadığı ise Denklem 2 ile ölçülmüştür.

$$
\begin{aligned}
& r_{t-1}^{d \text { orf }}=\ln \left(\text { Value }_{t-1}^{d \text { orf }}\right)-\ln \left(\text { Value }_{t-2}^{d \text { or } f}\right) \\
& s_{t}^{d \text { orf }}=\ln \left(\# \text { Share } t_{t}^{d \text { orf } f}\right)-\ln \left(\# \text { Share } e_{t-1}^{d \text { orf }}\right)
\end{aligned}
$$

Burada, "Value" portföyün toplam piyasa değerini; "\#Share", portföydeki toplam hisse miktarını; "d", yerli yatırımcı portföyünü; "f", yabancı yatırımcı portföyünü; "s", portföylerde bulunan hisse miktarlarındaki günlük logaritmik değişimi; "r" portföylerin piyasa değerinde meydana gelen günlük logaritmik değişimi ve t, günü ifade etmektedir. " $r$ " nin negatif (pozitif) bir sonuca sahip olması, t-1 günündeki portföy değerlerinin bir önceki güne (t-2) göre değer kaybettiğini (kazandığını); "s" nin negatif (pozitif) bir sonuca sahip olması ise $t$ gününde hisse senetlerine yönelik taleplerde bir önceki güne (t-1) göre azalış (artış) meydana geldiğini göstermektedir.

$\mathrm{Bu}$ çalışma; negatif ruh halinin, yatırımcı davranışlarına, yaşanan kayıpları takip eden ilk borsa işlem gününde etki edeceğini varsaymaktadır.

Kasım 2005 - Nisan 2015 dönemi aralığında yerli ve yabancı yatırımcıların portföylerinde bulunan günlük hisse miktarları ile bu portföylerin Pazar değerleri; Türkiye Merkezi Kayıt Kuruluşu'ndan temin edilmiştir ${ }^{2}$. Bu verilere ilişsin temel istatistikler Tablo 1'de gösterilmektedir. Tablo 1 ayrıca; analizlerde kullanılan diğer kontrol değişkenlerine ilişkin özet istatistiki bilgilere de yer vermektedir. Bu değişkenler, iyi bilinen takvimsel anomalileri, makroekonomik faktörleri ve alternatif ruh hali vekil değişkenlerini kontrol altına almak ve böylece analiz sonuçlarını robust kılmak amacıyla çalışma modeline dâhil edilmektedir.

Şekil 1, deneysel analizlere geçmeden önce, önceki kayılar ile hisse senetlerine yönelik talepler arasındaki ilişkiye öncü bir fikir oluşturması amacıyla çizilmiş̧ir. Şekil 1; kayıp yaşayan (negatif ruh halindeki) yatırımcıların, kayıpları takip eden ilk borsa işlem günlerinde portföylerindeki hisse miktarlarında (taleplerinde) meydana gelen değişimleri göstermektedir.

\footnotetext{
${ }^{2}$ MKK'dan 15.04.2015 tarihli resmi dilekçe ile talep edilen veriler, 06.05.2015 tarihinde ilgili kurum tarafindan yazarın resmi e-mail adresine gönderilmiştir.
} 


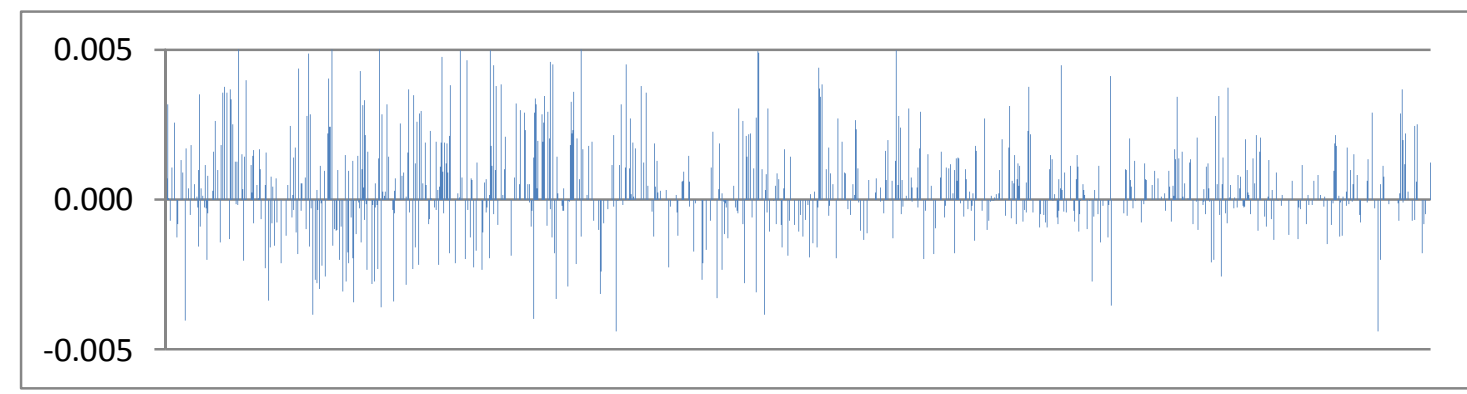

A- Yerli Yatırımcılar

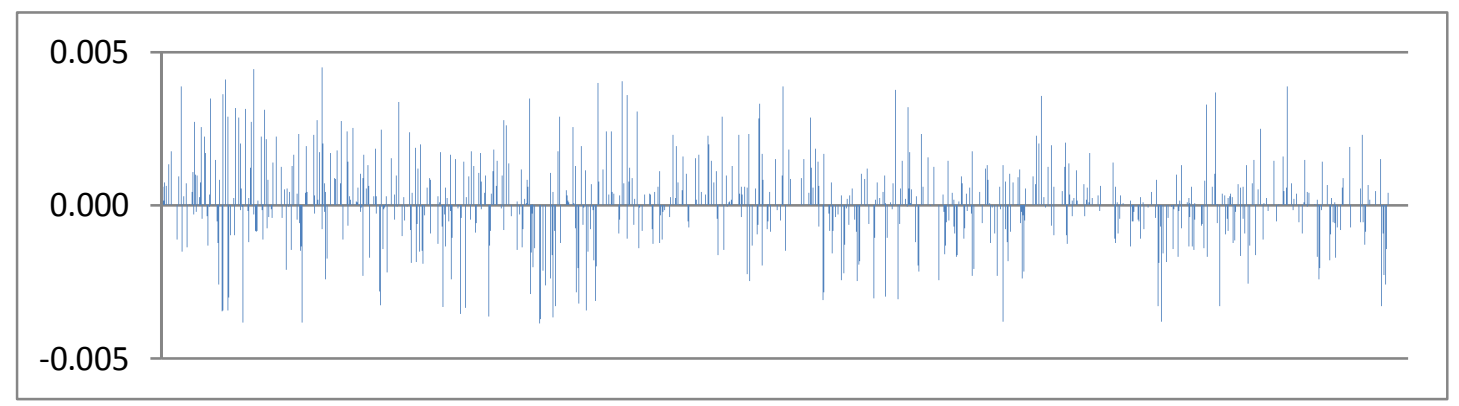

B- Yabancı Yatırımcilar

Şekil 1. Önceki Kayıpları Takip Eden İlk Borsa İşlem Günlerinde Hisse Taleplerinde Meydana Gelen Değişim Oranları

Tablo 1. Çalışmada Kullanılan Değişkenlerin Özet İstatistikleri

\begin{tabular}{|c|c|c|c|c|c|c|}
\hline & Dönem: Kasım 2005 - Nisan 2015 & Ortalama & St. Sapma & Medyan & Maksimum & Minimum \\
\hline \multirow{4}{*}{ A - } & Yerli Portföyünün Değeri (Value $)$ - Milyon TL & 50,557 & 22,324 & 51,958 & 93,598 & 16,807 \\
\hline & Yerli Portföyündeki Hisse Sayısı (\#share ${ }^{\mathrm{d}}$ ) - Milyon Adet & 15,616 & 6,535 & 14,395 & 25,620 & 5,310 \\
\hline & Yabanc1 Portföyünün Değeri (Valuef ${ }^{f}$ - Milyon TL & 94,017 & 623 & 93,583 & 169,008 & 33,356 \\
\hline & Yabancı Portföyündeki Hisse Sayısı (\#sharef $)$ - Milyon Ad. & 15,162 & 75 & 16,015 & 21,850 & 5,909 \\
\hline & $r^{d}$ & 0.000616 & 0.000329 & 0.001289 & 0.097829 & -0.094133 \\
\hline & $r^{f}$ & 0.000522 & 0.000341 & 0.001319 & -0.095946 & 0.109343 \\
\hline & $s^{d}$ & 0.000395 & 0.001630 & 0.000223 & 0.005234 & -0.004580 \\
\hline & $s^{f}$ & 0.000146 & 0.001400 & 0.000122 & 0.004499 & -0.004234 \\
\hline \multirow[t]{14}{*}{ C- } & Altın Fiyatlarındaki (\$/Ons) değişim & 0.000306 & 0.012491 & 0.000604 & 0.096891 & -0.061720 \\
\hline & $\begin{array}{l}\text { Brent Petrol Fiyatlarındaki (\$ / Varil) değişim } \\
\text { MAKROEKONOMIK DUYURULAR }\end{array}$ & 9.39E-06 & 0.020988 & 0.000000 & 0.198190 & -0.168320 \\
\hline & 1- TÜFE Verileri (Duyuru günü $=1 ; 0$ ) & 0.046725 & 0.211097 & 0 & 1 & 0 \\
\hline & 2- Dış Ticaret İstatistikleri (Duyuru günü $=1 ; 0$ ) & 0.045809 & 0.209118 & 0 & 1 & 0 \\
\hline & 3- İşü̈cü İstatistikleri (Duyuru günü $=1 ; 0)$ & 0.053596 & 0.22527 & 0 & 1 & 0 \\
\hline & 4- GSYİH Verileri (Duyuru günü $=1 ; 0$ ) & 0.015575 & 0.123852 & 0 & 1 & 0 \\
\hline & 5- Sanayi Üretim Endeksi (Duyuru günü = 1;0) & 0.053138 & 0.22436 & 0 & 1 & 0 \\
\hline & 6- Perakende Satış Hacmi Endeksi (Duyuru günü $=1 ; 0$ ) & 0.008704 & 0.092908 & 0 & 1 & 0 \\
\hline & 7- Ekonomik Güven Endeksi (Duyuru günü $=1 ; 0$ ) & 0.001374 & 0.037054 & 0 & 1 & 0 \\
\hline & 8- Tüketici Güven Endeksi (Duyuru günü = 1; 0) & 0.049015 & 0.215949 & 0 & 1 & 0 \\
\hline & 9- İnşaat Ciro ve Üretim Endeksi (Duyuru günü $=1 ; 0$ ) & 0.010536 & 0.102126 & 0 & 1 & 0 \\
\hline & 10- Yapı İzin İstatistikleri (Duyuru günü $=1 ; 0$ ) & 0.010536 & 0.102126 & 0 & 1 & 0 \\
\hline & 11- Para Politikası Kurul Kararı (Duyuru günü $=1 ; 0$ ) & 0.048557 & 0.214989 & 0 & 1 & 0 \\
\hline & 12- Reel Kesim Güven Endeksi (Duyuru günü = 1;0) & 0.003207 & 0.056549 & 0 & 1 & 0 \\
\hline
\end{tabular}




\begin{tabular}{|c|c|c|c|c|c|c|}
\hline & 13- Aylık Fiyat Gelişmeleri Raporu (Duyuru günü $=1 ; 0$ ) & 0.044434 & 0.206105 & 0 & 1 & 0 \\
\hline D- & 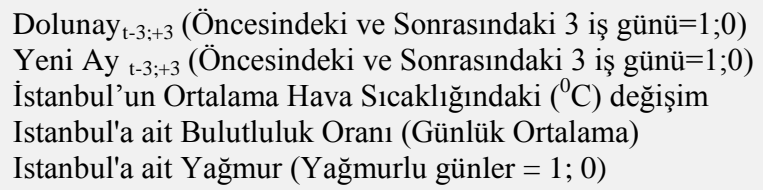 & $\begin{array}{l}0.232707 \\
0.234082 \\
-0.001406 \\
4.142694 \\
0.378836\end{array}$ & $\begin{array}{l}0.422654 \\
0.423520 \\
0.223424 \\
2.448290 \\
0.485208\end{array}$ & $\begin{array}{l}0 \\
0 \\
0.000000 \\
4.300000 \\
0\end{array}$ & $\begin{array}{l}1 \\
1 \\
1.400000 \\
10.000000 \\
1\end{array}$ & $\begin{array}{l}0 \\
0 \\
-2.710000 \\
0.000000 \\
0\end{array}$ \\
\hline E- & $\begin{array}{l}\text { Ocak Ayı }(\text { Ocak Ayı }=1 ; 0) \\
\text { Tatil Öncesi (Tatil öncesi günler }=1 ; 0) \\
\text { Tatil Sonrası (Tatil sonrası günler }=1 ; 0) \\
\text { Pazartesi Günü }(\text { Pazartesi }=1 ; 0) \\
\text { Ramazan Ayı (Ramazan Ayı }=1 ; 0)\end{array}$ & $\begin{array}{l}0.089327 \\
0.023820 \\
0.024279 \\
0.191480 \\
0.000009\end{array}$ & $\begin{array}{l}0.285280 \\
0.152524 \\
0.153948 \\
0.393556 \\
0.020988\end{array}$ & $\begin{array}{l}0 \\
0 \\
0 \\
0 \\
0\end{array}$ & $\begin{array}{l}1 \\
1 \\
1 \\
1 \\
1 \\
\end{array}$ & $\begin{array}{l}0 \\
0 \\
0 \\
0 \\
0\end{array}$ \\
\hline & $\begin{array}{l}\text { trol değişkenlerine; D bölümü, alternatif ruh hali vekil de } \\
\text { imsel değişkenlere ilişkin istatistikleri sunmaktadır. (b) Ala } \\
\text { hariç) ilişkin istatistiklerden sadece Ocak ayına ve ha } \\
\text { istiklerden ise sadece Pazartesi gününe ait istatistiklere ye } \\
\text { amın1, } 11.05 .2015 \text { tarihli resmi yazı ile Meteoroloji Genel } \\
\text { hinde yazarın resmi mail adresine iletilmiştir. } \\
\text { ://www.tuik.gov.tr/takvim/tkvim.zul\#tb2 ile http://www.tcn } \\
\text { sa Istanbul'un web sitesinden (http://www.borsaistanbul.c } \\
\text { rmation Administration'ın web sitesinden (http://www.ei }\end{array}$ & $\begin{array}{l}\text { Müdürlü } \\
\text { er verilmi } \\
\text { ( }) \\
\text { mb.gov.tr/ } \\
\text { com), } 14 \\
\text { ia.gov/) } 1\end{array}$ & $\begin{array}{l}\text { (j) } \\
\text { croekono } \\
\text { eslerind } \\
015 \text { tar }\end{array}$ & $\begin{array}{l}\text { dilmiş } \\
\text { k duy } \\
\text { temin ec } \\
\text { de ve l } \\
\text { inde te }\end{array}$ & $\begin{array}{l}\text { gili veriler, } \\
\text { ara ilişk } \\
\text { ştir. (') } \mathrm{Al} \\
\text { l fiyatları, }\end{array}$ & $\begin{array}{l}\text { in tarihler } \\
\text { ltın fiyatları } \\
\text { US Enegy } \\
\text { (f) Sürekl }\end{array}$ \\
\hline
\end{tabular}

\section{AMPRIKK ANALIZZLER}

Hisse senetlerine yönelik talep ile negatif ruh halini temsil eden önceki kayplar arasındaki ilişkinin belirlenmesinde kullanılacak olan temel yöntem, basit sıradan en kü̧̈ük kareler (ordinary least squares - OLS) regresyon yöntemidir. OLS regresyon analizlerinin en önemli problemi, verilerin aykırı değerlere (outlier) sahip olması problemidir (Rousseeuw ve Leroy, 1987). Aykırı değerler; veri setindeki gözlem değerlerinin çoğunluğunun sahip olduğu karakteristiğe sahip olmayan ve kestirim sonuçların büyük ölçüde etkileyen, az sayıdaki gözlem değerleridir. Aykırı değerlere sahip bir veri seti ile yürütülen OLS regresyon analizleri, sapmalı ve tutarsız sonuçlar vermektedir. Bu çalışmada, aykırı değerlerin olumsuz etkilerini gidermek için aykırı değerler tespit edilmiş ve OLS regresyon analizlerinin dışında bırakılmıştır $^{3}$. Aykırı değerlerden arındırılmış serilerle gerçekleştirilen OLS Regresyon analizleri, Newey-West tahmincisi ${ }^{4}$ kullanılarak yapılmıştır.

\footnotetext{
${ }^{3}$ Endekslere ilişkin aykırı değerler manuel olarak Iglewicz ve Hoaglin'in (1993) modifiye edilmiş Z skoru (M) yardımıyla tespit edilmiştir. Modifiye edilmiş $Z$ skoru (M) şu şekilde hesaplanır: $M_{i}=0.6745\left(x_{i}-\tilde{x}\right) /$ MAD . Burada $x_{i}$, serinin i dönemindeki değerini; $\tilde{x}$, serinin medyanını ve MAD $=$ median $\left\{\left|x_{i}-\tilde{x}\right|\right\}$ ifade etmektedir.

${ }^{4}$ Newey-West tahmincisi, regresyon denklemlerindeki hata terimlerinin heteroskedastisite ve otokorelasyon sorununa sahip olabilme ihtimaline karşı sağlıklı (robust) standart hatalar vermekte ve böylece tutarlı katsayı tahminlerinin yapılmasına imkân tanımaktadır.
} 


\subsection{Temel Model}

Çalışmada, $\mathrm{H}_{1 \mathrm{a}}$ ve $\mathrm{H}_{1 \mathrm{~b}}$ hipotezlerinin test edilebilmesi amacıyla ilk olarak aşağıdaki regresyon modeli (Denklem 3) çözümlenmektedir.

$$
\mathrm{s}_{\mathrm{t}}^{\mathrm{d} \text { or } \mathrm{f}}=\alpha+\beta_{1}\left(Z_{\mathrm{t}-1}^{\mathrm{d} \text { orf }} \times\left|\mathrm{r}_{\mathrm{t}-1}^{\mathrm{d} \text { orf }}\right|\right)+\omega_{1} \mathrm{PRE}_{\mathrm{t}}+\omega_{2} \mathrm{POST}_{\mathrm{t}}+\sum_{n=1}^{11} \gamma_{n} M_{n t}+\sum_{k=1}^{4} \rho_{\mathrm{k}} W_{k t}+\aleph_{1} \mathrm{DMR}_{\mathrm{t}}+\varepsilon_{t}
$$

Burada yer alan " $\mathrm{Z}_{\mathrm{t}-1}$ " bir önceki günde kayıp yaşanması durumunda 1 aksi takdirde 0 değerini alan kukla değişkendir. " $\left|\mathrm{r}_{\mathrm{t}-1}\right|$ ”, önceki günde logaritmik olarak hesaplanan portföy getirilerinin mutlak değeridir. $\mathrm{PRE}_{\mathrm{t}}\left(\mathrm{POST}_{\mathrm{t}}\right.$ ), $\mathrm{t}$ gününden bir gün önceki (sonraki) tatil günlerini; $\mathrm{M}_{\mathrm{nt}}$, yılın on bir ayını (aralık ayı hariç); $\mathrm{W}_{\mathrm{kt}}$, hafta içi günlerden dördünü (Çarşamba günü hariç) ve $\mathrm{DMR}_{t}$, Ramazan ayına denk gelen günleri ifade eden kukla değişkenlerdir ( $\mathrm{Bu}$ tür kukla değişkenler ilgili günlerde 1 aksi takdirde 0 değerini almaktadırlar).

İyi bilinen takvim anomalilerinin yukarıdaki regresyon modelinde (Denklem 3) kukla değişken olarak kullanılmasının nedeni, ilgili anomalilerin bağımlı değişken üzerindeki etkisini kontrol altına alarak analiz sonuçlarının sağlamlığını (robustness) tesis etmektir.

Çalışmada ayrı ayrı ele alınan yerli ve yabancı yatırımcılara ilişkin regresyon analizi sonuçları, Tablo 2'de raporlanmaktadır.

Tablo 2'ye göre; $\beta_{1}$ katsayısı yerli yatırımcılar için pozitif fakat yabancı yatırımcılar için negatiftir. Yerli ve yabancı yatırımcılar için tahmin edilen bu iki katsayı da \%1 anlamlılık seviyesinde istatistiksel olarak anlamlıdır; başka bir ifadeyle $\beta_{1}$ 'in sıfır olduğu "null" hipotezi reddedilmektedir. $\beta_{1}$ katsayısının pozitif işareti (yerli yatırımcılar için) ortaya koymaktadır ki; her şey sabitken, t-1 gününde yaşanan kayıpların artması, t gününde yerli yatırımcıların hisse senetlerine yönelik taleplerini artırmaktadır. Daha açık bir değişle; her şey sabitken, t-1 gününde, kayıp oranında meydana gelecek \%1'lik bir artışın, yerli yatırımcıların t günündeki hisse taleplerinde yaklaşık olarak \%0.02'lik bir artışı (t-1 gününe göre) beraberinde getireceği tahmin edilmektedir ${ }^{5}$. Aynı durumda yabancı yatırımcıların hisse taleplerinin ise $\beta_{1}$ katsayısının negatif işaretinden ötürü \%0.45 oranında düşüş göstereceği tahmin edilmektedir.

İlk model için elde edilen bulgular; önceki kayıpların arttığı yani yatırımcılar üzerinde negatif ruh halinin egemen olduğu günlerde, riskli varlıklara (yani hisse senetlerine) yönelik talebin yerli yatırımcılar açısından artacağı fakat yabancı yatırımcılar açısından ise azalacağını açıkça ortaya koymaktadır. Özetle yerli yatırımcılar çalışma hipotezlerinden $\left(\mathrm{H}_{1 \mathrm{~b}}\right)$

\footnotetext{
${ }^{5} \mathrm{E}\left(\mathrm{s}_{\mathrm{t}}\right)-\mathrm{E}\left(\mathrm{s}_{\mathrm{t}-1}\right) \quad=\beta_{1} \times \ln \left(\right.$ önceki kaylp $\left.p_{T-1}\right)-\beta_{1} \times \ln \left(\right.$ önceki kaylp $\left.\mathrm{t}_{\mathrm{t}-1}\right)$

$=0.020042 \times \ln ($ önceki kayıp $t-1 * 1.01)-0.020042 \times \ln \left(\right.$ önceki kayıp $\left.{ }_{t-1}\right)$

$=0.020042 \times\left[\ln (\right.$ önceki kay1p $t-1 * 1.01)-\ln \left(\right.$ önceki kaypp $\left.\left._{t-1}\right)\right]$

$=0.020042 \times \ln \left[(\right.$ önceki kayıp $t-1 * 1.01) /\left(\right.$ önceki kayıp $\left.\left.{ }_{t-1}\right)\right]$

$=0.020042 \times \ln (1.01)$

$=0.0002$
} 
ile örtüş̧en davranışlarda bulunurken yabancı yatırımcılar ise $\left(\mathrm{H}_{1 \mathrm{a}}\right)$ hipotezi ile örtüşen davranışlarda bulunmaktadırlar.

Geriye kalan değişkenlere gelince; Haziran ve Kasım ayları ile Pazartesi günü kukla değişkenlerinin katsayıları, yerli yatırımcılar için pozitif ve istatistiksel açıdan anlamlıdır (Eylül ayı kukla değişkeni ise negatiftir). Yerli yatırımcıların sözgelimi Pazartesi günündeki ortalama hisse talebi, diğer günlerdeki ortalama talep miktarlarından yaklaşık olarak 0.01 baz puan daha yüksektir. Yabancı yatırımcılar açısından ise Nisan, Haziran ve Temmuz ayları ile Cuma günü kukla değişkenlerinin katsayıları pozitif ve istatistiksel açıdan anlamlıdır.

Son olarak, bağımsız değişkenler bir bütün olarak dikkate alındığında, bütün bağımsız değişkenlerin katsayılarının sıfira eşit olduğu hipotezi, hem yerli hem de yabancı yatırımcılar için oluşturulan modellerce reddedilmektedir (sırasıyla $\mathrm{F}$ istatistik değerleri; 4.733, 6.314).

\subsection{Ekonomik Göstergelerin Kontrol Altına Alındığı Model}

Denklem 3'teki Regresyon modeli, makroekonomik değişkenleri içermemektedir; hâlbuki makroekonomik değişkenlerde meydana gelen değişimler, firmaların gelecekteki nakit akımlarını ve sermaye maliyetlerini etkilemek suretiyle hisse fiyatlarına (dolayısıyla hisse taleplerine) tesir edebilmektedir (Ibrahim ve Yusoff, 2001). Bu bağlamda; takvim anomalilerinin yanında bir de ekonomik değişkenlerin bağımlı değişken üzerindeki etkisini kontrol altına alarak analiz sonuçlarının sağlamlığını (robustness) tesis etmek gerekir. Bu doğrultuda Denklem 3'e, 15 farklı makroekonomik değişken ilave edilmiş ve aşağıdaki regresyon modeli (Denklem 4) oluşturulmuştur.

$$
\begin{aligned}
\mathrm{s}_{\mathrm{t}}^{\mathrm{d} \text { or } \mathrm{f}} & =\alpha+\beta_{1}\left(Z_{\mathrm{t}-1}^{\mathrm{d} \text { orf }} \times\left|\mathrm{r}_{\mathrm{t}-1}^{\mathrm{d} \text { or } \mathrm{f}}\right|\right)+\omega_{1} \mathrm{PRE}_{\mathrm{t}}+\omega_{2} \mathrm{POST}_{\mathrm{t}}+\sum_{n=1}^{11} \gamma_{n} M_{n t}+\sum_{k=1}^{4} \rho_{\mathrm{k}} W_{k t}+\aleph_{1} \mathrm{DMR}_{\mathrm{t}} \\
& +\delta_{1} G O L D_{t-1}+\delta_{2} \text { OIL }_{t-1}+\delta_{3} \mathrm{r}_{\mathrm{t}-1}^{\mathrm{f} \text { or }}+\sum_{\mathrm{m}=1}^{13} \lambda_{\mathrm{m}} \mathrm{ANNOUNCE}_{m t}+\varepsilon_{t}
\end{aligned}
$$

Burada yer alan $\mathrm{GOLD}_{\mathrm{t}-1}\left(\mathrm{OIL}_{\mathrm{t}-1}\right)$, altının (brent petrolün) dolar fiyatlarının, $\mathrm{t}-1$ günündeki günlük logaritmik değişimidir. ANNOUNCE ${ }_{\mathrm{mt}}$, çalışma kapsamında ele alınan 13 makroekonomik göstergenin (Tablo 1) her biri için ayrı ayrı olmak üzere, $t$ gününde makroekonomik bir duyuru yapılması durumunda 1; aksi takdirde 0 değerini alan kukla değişkenler setidir.

OLS regresyon analizi sonuçlarına göre (Tablo 2), yerli yatırımcıların hisse senedi talepleri; analiz dönemi boyunca Ekonomik Güven Endeksine (duyuru 7) ve Para Politikas1 Kurulu Kararlarına (duyuru 11) ilişkin duyurulara pozitif yönde fakat yabancı yatırımcının önceki gündeki getirilerine $\left(\mathrm{r}_{\mathrm{t}-1}^{\mathrm{f}}\right)$ istatistiksel olarak anlamlı bir şekilde negatif yönde tepki vermiş̧tir. Yabancı yatırımcıların hisse senedi talepleri ise; TÜFE Verilerine (duyuru 1) ve Tüketici Güven Endeksine (duyuru 8) ilişkin duyurulara pozitif yönde fakat Perakende Satış Hacmi Endeksine (duyuru 6), Ekonomik Güven Endeksine (duyuru 7), Reel Kesim Güven Endeksine (duyuru 12) ve Aylık Fiyat Gelişmeleri Raporuna (duyuru 13) istatistiksel olarak 
anlamlı bir şekilde negatif yönde tepki vermiştir. Bu tespitler, yerli ve yabancı yatırımcıların farklı makroekonomik duyuruları dikkate alarak yatırım yaptıklarının bir kanıtı niteliğindedir.

Denklem (3)'e yapılan yeni ilavelere karşın $\beta_{1}$ katsayısına ilişkin sonuçlar istatistiksel açıdan anlamlı ve yerli yatırımcılar için halen pozitif, yabancı yatırımcılar için ise halen negatiftir. Bu sonuç; negatif ruh hali ile hisse senetlerine yönelik talepler arasındaki ilişkinin, yatırımcıların ekonomik göstergelere verdiği tepki ile değişmediğini ortaya koymaktadır.

\subsection{Ruh Haline Etki Eden Diğer Değişkenlerin Kontrol Altına Alındığı Model}

Birçok bilim adamı, hisse senedine yönelik taleplerin (ya da hisse fiyatlarının), yatırımcının ruh haline etki eden dış kaynaklı faktörlere (sıcaklık gibi) verdiği tepkiyi incelemektedir (bakınız, literatür taraması). Çalışmaların çoğu ortak bulgulara sahiptir; Örneğin mevsimsel duygu durum bozukluğunun (seasonal affective disorder-SAD) veya hava durumunun etkisi ile hisse senedine yönelik talepler düşebilmektedir (Kamstra vd., 2003; Saunders, 1993). Bu noktada birileri; ruh haline etki eden diş kaynaklı faktörlerin dikkate alınması suretiyle (literatürde kullanıldığı şekliyle) negatif ruh hali (önceki kayıplar) ile hisse senetlerine yönelik talep arasında bu çalışmada tespit edilen ilişkilerin ortadan kalkıp kalkmayacağını merak edebilir. Bu merakın giderilmesi, alternatif ruh hali vekil değişkenlerinin kontrol altına alınması ile mümkündür. Bu nedenle Denklem 4, aşağıdaki gibi revize edilmiştir.

$$
\begin{aligned}
\mathrm{s}_{\mathrm{t}}^{\mathrm{d} \text { or } \mathrm{f}} & =\alpha+\beta_{1}\left(Z_{\mathrm{t}-1}^{\mathrm{d} \text { or } \mathrm{f}} \times\left|\mathrm{r}_{\mathrm{t}-1}^{\mathrm{d} \text { or }}\right|\right)+\omega_{1} \mathrm{PRE}_{\mathrm{t}}+\omega_{2} \text { POST }_{\mathrm{t}}+\sum_{n=1}^{11} \gamma_{n} M_{n t}+\sum_{k=1}^{4} \rho_{\mathrm{k}} W_{k t}+\aleph_{1} \mathrm{DMR}_{\mathrm{t}} \\
& +\delta_{1} \text { GOLD }_{t-1}+\delta_{2} \text { OIL }_{\mathrm{t}-1}+\delta_{3} \mathrm{r}_{\mathrm{t}-1}^{\mathrm{f} \text { or }}+\sum_{\mathrm{m}=1}^{13} \lambda_{\mathrm{m}} \text { ANNOUNCE }_{m t}+\xi_{1} \mathrm{SAD}_{\mathrm{t}}+\xi_{2} \text { NMOON }_{\mathrm{t}} \\
& +\xi_{3} \text { FMOON }_{\mathrm{t}}+\xi_{4} \text { TEMP }_{\mathrm{t}}+\xi_{5} \text { CLOUD }_{\mathrm{t}}+\xi_{6} \text { PRECIPITATION }_{\mathrm{t}}+\varepsilon_{t}
\end{aligned}
$$

Burada yer alan $\mathrm{NMOON}_{\mathrm{t}}\left(\mathrm{FMOON}_{\mathrm{t}}\right)$, Yeni AY (Dolun AY) zamanlarından önceki ve sonraki üç günü ve PRECIPITATION ${ }_{t}$, İstanbul'da yağmurun yağdığı günleri temsil eden kukla değişkenlerdir ( $\mathrm{Bu}$ kukla değişkenler ilgili günlerde 1 aksi takdirde 0 değerini almaktadırlar). TEMP $\mathrm{t}$, İstanbul'un hava sıcaklığındaki $\left({ }^{0} \mathrm{C}\right)$ günlük logaritmik değişimlerdir. $\mathrm{CLOUD}_{\mathrm{t}}$, İstanbul'daki bulutluluk oranlarıdır. Son olarak $\mathrm{SAD}_{\mathrm{t}}$ de İstanbul'un $\mathrm{t}$ günündeki ortalama gece süresinin standardize edilmiş değeridir ${ }^{6}$.

Denklem 5'e ilişkin regresyon analizlerinin sonuçları Tablo 2'de sunulmaktadır. Tablo 2 'de yer alan $\beta_{1}$ katsayısının işareti ve büyüklüğü, Denklem 4'ün sonuçları ile örtüşmektedir. Sonuçlara göre; her şey sabitken, önceki kayıplarda meydana gelecek \%20’lik bir artışın,

\footnotetext{
${ }^{6}$ SAD, Kamstra vd. (2003) de olduğu gibi hesaplanmaktadır: Ht= Güneşin batışından güneşin doğuşuna kadar geçen süredir.$$
\mathrm{SAD}_{\mathrm{t}}= \begin{cases}\mathrm{H}_{\mathrm{t}}-12 & \text { Kış ve Sonbahar Ayları İçin } \\ 0 & \text { Aksi Takdirde }\end{cases}
$$ 
sonraki günde yerli yatırımcıların hisse taleplerinde $\% 0.15$ 'lik bir artışı, buna karşın yabancı yatırımcıların hisse taleplerinde ise \%0.46'lik bir azalışı beraberinde getireceği tahmin edilmektedir.

Regresyon analizinin sonuçlarına göre (Tablo 2, Denklem 5); SAD, Dolunay ve Bulutluluk değişkenlerinin katsayıları, yerli yatırımcılar açısından pozitif ve istatistiksel olarak anlamlıdır; buna karşın Yeni Ay değişkeninin katsayısı ise negatiftir. Yabancı yatırımcı talepleri açısından ise salt Dolunay değişkeni istatistiksel açıdan anlamlı ancak negatiftir.

Yukarıda sözü edilen bulgular oldukça ilginç ve dikkat çekici olmakla birlikte çalışmanın bu kısmına kadar $\beta_{1}$ katsayılarına yönelik ortaya konulan tespitleri robust kılmaktadır. Şöyle ki çalışmanın literatür kısmında yer bulan çalışmalar incelendiğinde SAD, Dolunay ve Bulutluluk değişkenlerinin negatif ruh halinin temsilcisi olarak kabul edildiği görülür. Denklem 5'e ilişkin sonuçlar incelendiğinde tıpkı önceki kayıpların yaşandığı günlerde olduğu gibi gece süresinin uzamasında, Dolunay günlerinde ve bulutluluk oranlarının arttığı günlerde (yani negatif ruh halinin egemen olduğu günlerde), yerli yatırımcıların hisse taleplerinin arttığı açığa çıkmaktadır. Yabancı yatırımcılar açısından ise Dolunay günlerinde (yani negatif ruh halinde) hisse senetlerine yönelik taleplerde azalış yaşandığı görülmektedir. Bu tespitler çalışmanın önceki kısımlarında $\beta_{1}$ katsayılarına ilişkin yapılan yorumlarla tutarlılık göstermekte ve negatif ruh hali - hisse talebi arasinda bu çalışmada ortaya konulan ilişkilere güçlü kanıtlar sunmaktadır.

Sonuç olarak negatif ruh hali ile hisse talebi arasında yerli ve yabancı yatırımcılar açısından ayrı yarı tespit edilen ilişkiler; ayın görünümü etkisi, yağmurun etkisi, bulutluluk oranı etkisi, SAD etkisi ve sicaklık etkisi gibi iyi bilinen anomalilerin de kontrol altına alınmasından sonra bile halen devam etmektedir.

\section{4. “t-1” Gününde Meydana Gelen Kaybın “t” Gününde Geri Kazanılma İhtimalini Kontrol Altına Alan Model}

Thaler ve Johnson'a (1990) göre, negatif ruh haline sahip kişiler (yani daha öncesinde kayıplar yaşamış kişiler), zararlarını telafi etme fırsatını veren riskli tercihleri daha çekici bulmaktadırlar (break-even effects). Yani yatırımcıların hisse senetlerine (riskli varlıklara) yönelik taleplerini artırmalarının tek şartı, bugün yapacakları yatırım sayesinde dünkü kayıplarını karşılama ihtimalinin artmış olmasıdır.

Çalışmanın bu alt bölümü, Thaler ve Johnson'un (1990) iddiasının Borsa İstanbul'daki yatırımcılar açısından ne derece geçerli olduğunu ortaya koymak $\left(\mathrm{H}_{1 \mathrm{c}}\right.$ hipotezini test etmek) için tasarlanmıştır. Bu doğrultuda Denklem 5 ile oluşturulan model, dünkü kayıpları geri kazanma ihtimallerinin de modele dâhil edilmesi suretiyle genişletilmiştir (Denklem 6). 


$$
\begin{aligned}
\mathrm{s}_{\mathrm{t}}^{\mathrm{d} \text { orf }} & =\alpha+\beta_{1}\left(Z_{\mathrm{t}-1}^{\mathrm{d} \text { orf }} \times \mathrm{P}_{\mathrm{t}}^{\mathrm{d} \text { orf }}\right)+\omega_{1} \mathrm{PRE}_{\mathrm{t}}+\omega_{2} \text { POST }_{\mathrm{t}}+\sum_{n=1}^{11} \gamma_{n} M_{n t}+\sum_{k=1}^{4} \rho_{\mathrm{k}} W_{k t}+\aleph_{1} \mathrm{DMR}_{\mathrm{t}} \\
& +\delta_{1} \text { GOLD }_{t-1}+\delta_{2} \text { OIL }_{t-1}+\delta_{3} \mathrm{r}_{\mathrm{t}-1}^{\mathrm{f} \text { or d }}+\sum_{\mathrm{m}=1}^{13} \lambda_{\mathrm{m}} \text { ANNOUNCE }_{m t}+\xi_{1} \mathrm{SAD}_{\mathrm{t}}+\xi_{2} \text { NMOON }_{\mathrm{t}} \\
& +\xi_{3} \text { FMOON }_{\mathrm{t}}+\xi_{4} \text { TEMP }_{\mathrm{t}}+\xi_{5} \text { CLOUD }_{\mathrm{t}}+\xi_{6} \text { PRECIPITATION }_{\mathrm{t}}+\varepsilon_{t}
\end{aligned}
$$

Burada yer alan “ $\mathrm{P}_{\mathrm{t}}$ ”, t-1 gününde yaşanan kaybın, t gününde telafi edilme ihtimalidir.

“ $\mathrm{P}_{\mathrm{t}}$ ” günlük bazda logaritmik olarak hesaplanan portföy getirilerinin standardize normal dağılım değerlerinden yararlanılarak hesaplanmıştır. Öncesinde kayıp yaşanan her bir gün için ayrı ayrı olmak üzere, o gün, dünkü kaybın telafi edilme ihtimali (yani dünkü kaybın mutlak değeri üzerinde kazanç sağlama ihtimali) Denklem 7, 8 ve 9 yardımıyla hesaplanmıştır (Bradley, 2007; 270-271).

$x \sim N\left(\mu, \frac{\sigma^{2}}{n}\right)$

$\mathrm{Z}=\frac{x-\mu}{\sigma / \sqrt{n}}$

$P(x>\mid$ önceki Kayıp $\mid)=P\left(Z>\frac{\| \text { Önceki Kayıp } \mid-\mu}{\sigma / \sqrt{n}}\right)$

Denklem 7,8 ve 9'da yer alan $x$, günlük olarak hesaplanan portföy getirilerini; $\mu$, kazanç ihtimalinin hesaplanacağı günden önceki tüm portföy getirilerinin ortalamasını; $\sigma$, kazanç ihtimalinin hesaplanacağı günden önceki tüm portföy getirilerinin standart sapmasını; Z, kazanç ihtimaline karşılık gelen tablo değerlerini yani normal dağılıma sahip portföy getirilerinin standart normal dağılım değerlerini ve $\mathrm{P}$, yatırımcının kazanç ihtimalini, diğer bir ifadeyle bugünkü kazancın dünkü kaybın mutlak değerinin üstünde olma ihtimalini temsil etmektedir (Şekil 2).

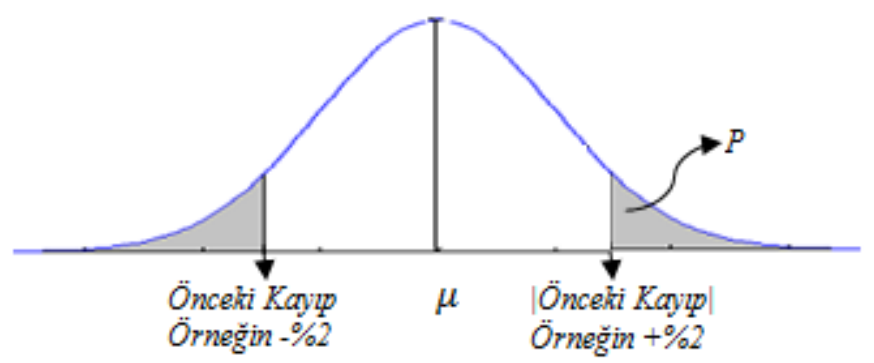

Şekil 2. Standardize Normal Dağılım Değeri İle Kazanç Olasılı̆̆

Tablo 2'de yer alan Denklem 6'nın sonuçlarına göre; $\beta_{1}$ katsayısı sadece yabancı yatırımcılar için pozitif ve $\% 5$ anlamlılık seviyesinde istatistiksel olarak anlamlıdır; başka bir ifadeyle $\beta_{1}$ 'in sıfır olduğu "null” hipotezi salt yabancı yatırımcılar açısından reddedilmektedir. $\beta_{1}$ katsayısının pozitif işareti (yabancı yatırımcılar için) ortaya koymaktadır ki; her şey sabitken, $\mathrm{t}-1$ gününde yaşanan kayıpların $\mathrm{t}$ gününde telafi edilme olasılı̆̆ı arttıkça yabancı 
yatırımcıların hisse senetlerine yönelik talepleri de artırmaktadır. Bu ilişki daha açık bir ifadeyle şu şekilde açıklanabilir. Diyelim ki geçmişteki t-1 günlerde yaşanan her kaybın yine geçmişteki t günlerde yabancı yatırımcılar tarafından geri kazanılma olasılıklarının ortalaması \%5’tir. Yine diyelim ki önümüzdeki herhangi bir t-1 gününde yaşanan kayıp oranının bir sonraki $t$ gününde geri kazanılma ihtimali de $\% 20$ olarak hesaplansın. Bu varsayımlara göre; yabancı yatırımcıların ilgili t günündeki hisse taleplerinin t-1 gününe göre yaklaşık olarak $\% 0.052$ oranında artacağ 1 tahmin edilir ${ }^{7}$.

Buraya kadar ortaya konulan bulgular, oldukça ilginç olarak nitelenmekte ve negatif ruh halindeki yerli yatırımcıların, önceki günkü kayıplarını telafi etme olasılığını dikkate almak yerine salt ruh hallerini düzeltmek amacıyla hisse senetlerine yönelik taleplerini artırdığını göstermektedir. Yerli yatırımcı davranışına tezat bir şekilde yabancı yatırımcılar ise negatif ruh halindeyken riskli varlıklara (hisse senetlerine) yönelik taleplerini azaltmakta (Denklem 3, 4 ve 5) ancak önceki kayıplarını telafi etme olasılıkları bulunduğunda ise riskli varlıklara yönelik taleplerini artırmaktadırlar (Denklem 6).

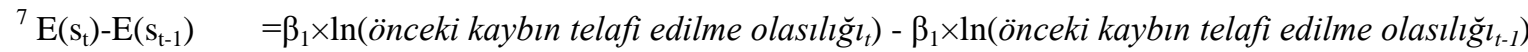
$=0.000378 \times \ln (\% 20)-0.000378 \times \ln (\% 5)$

$=0.00052$
} 
Tablo 2. Regresyon Analizinin Sonuçları (Denklem 3 - 6).

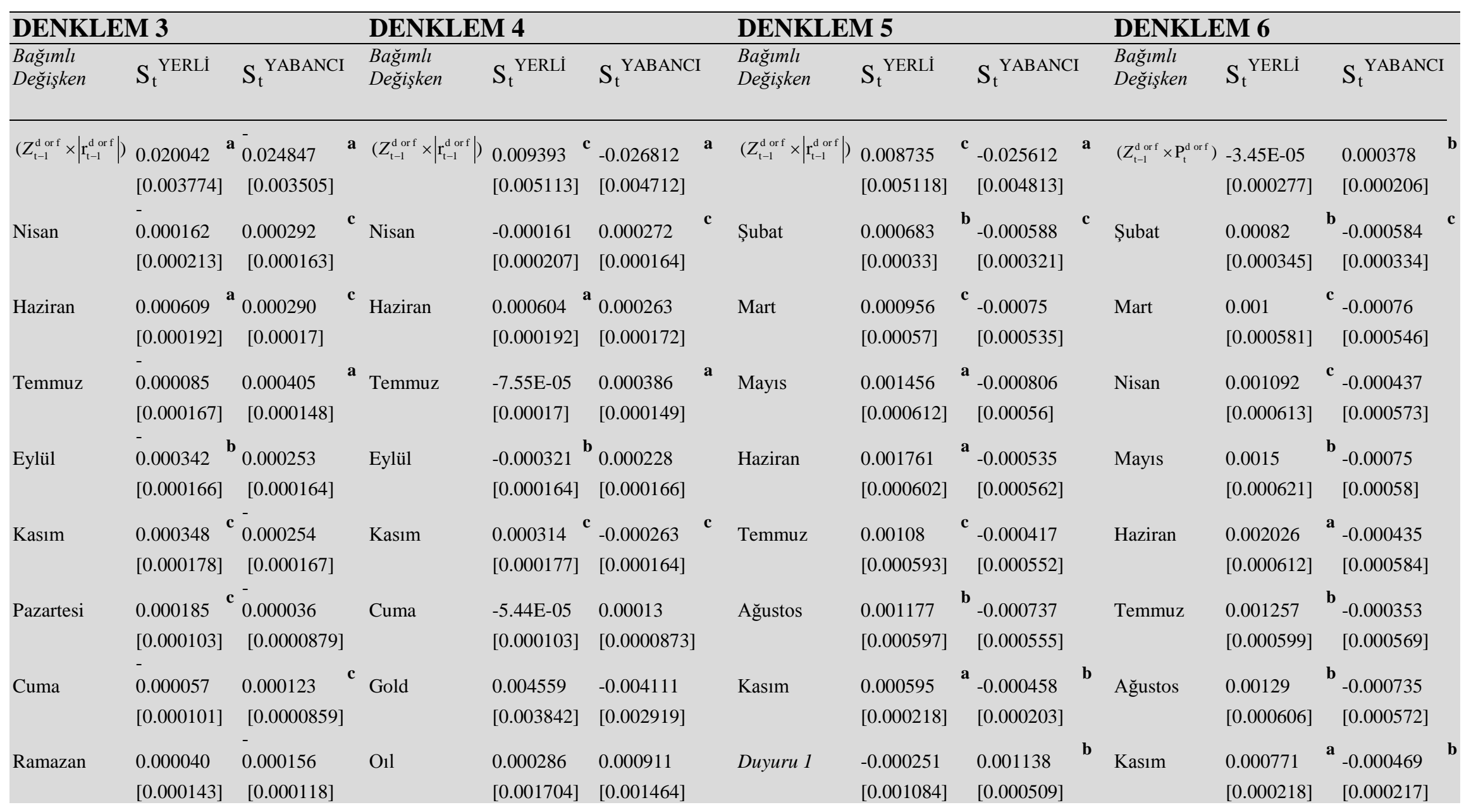




\begin{tabular}{|c|c|c|c|c|c|c|c|c|c|c|c|c|c|c|}
\hline \multirow[t]{14}{*}{ Sabit } & $\begin{array}{l}0.000202 \\
{[0.000133]}\end{array}$ & $\begin{array}{l}0.000190 \\
{[0.000122]}\end{array}$ & c Duyuru 1 & $\begin{array}{l}-0.000177 \\
{[0.001098]}\end{array}$ & $\begin{array}{l}0.001093 \\
{[0.000509]}\end{array}$ & b & Duyuru 6 & $\begin{array}{c}-5.34 \mathrm{E}-05 \\
{[0.00022]}\end{array}$ & $\begin{array}{l}-0.00046 \\
{[0.000261]}\end{array}$ & c & Duyuru 1 & $\begin{array}{l}-0.003426 \\
{[0.000907]}\end{array}$ & $\begin{array}{l}{ }^{\mathrm{a}} 0.002791 \\
\\
{[0.000224]}\end{array}$ & a \\
\hline & & & Duyuru 6 & $\begin{array}{l}4.34 \mathrm{E}-05 \\
{[0.000218]}\end{array}$ & $\begin{array}{l}-0.000511 \\
{[0.000257]}\end{array}$ & b & Duyuru 7 & $\begin{array}{l}0.001153 \\
{[0.000585]}\end{array}$ & $\begin{array}{l}{ }^{b}-0.001419 \\
{[0.000767]}\end{array}$ & c & Duyuru 6 & $\begin{array}{l}-0.000172 \\
{[0.000189]}\end{array}$ & $\begin{array}{l}-0.000472 \\
{[0.000276]}\end{array}$ & \\
\hline & & & Duyuru 7 & $\begin{array}{l}0.000993^{\mathbf{C}} \\
{[0.000622]}\end{array}$ & $\begin{array}{l}-0.001297 \\
{[0.000806]}\end{array}$ & c & Duyuru 8 & $\begin{array}{l}-0.000174 \\
{[0.000149]}\end{array}$ & $\begin{array}{l}0.000221 \\
{[0.000129]}\end{array}$ & c & Duyuru 7 & $\begin{array}{l}0.000794 \\
{[0.000484]}\end{array}$ & $\begin{array}{c}{ }^{\text {c }}-0.001332 \\
{[0.000771]}\end{array}$ & c \\
\hline & & & Duyuru 8 & $\begin{array}{l}-0.000192 \\
{[0.000151]}\end{array}$ & $\begin{array}{l}0.000231 \\
{[0.000131]}\end{array}$ & c & Duyuru 11 & $\begin{array}{l}0.000305 \\
{[0.000159]}\end{array}$ & $\begin{array}{l}{ }^{c}-0.000118 \\
{[0.000129]}\end{array}$ & & Duyuru 13 & $\begin{array}{l}0.003372 \\
{[0.000908]}\end{array}$ & $\begin{array}{c}{ }^{\mathrm{a}}-0.002493 \\
{[0.000239]}\end{array}$ & a \\
\hline & & & Duyuru 11 & $\begin{array}{l}0.00025 \quad \mathbf{c} \\
{[0.000158]}\end{array}$ & $\begin{array}{l}-9.11 \mathrm{E}-05 \\
{[0.000126]}\end{array}$ & & Duyuru 12 & $\begin{array}{l}6.34 \mathrm{E}-05 \\
{[0.000511]}\end{array}$ & $\begin{array}{l}-0.000539 \\
{[0.000309]}\end{array}$ & c & $\mathrm{R}^{\mathrm{f} \text { or d }}{ }_{(\mathrm{t}-1)}$ & $\begin{array}{l}-0.196121 \\
{[0.074638]}\end{array}$ & $\begin{array}{l}{ }^{\mathbf{a}}-0.043936 \\
{[0.013106]}\end{array}$ & a \\
\hline & & & Duyuru 12 & $\begin{array}{l}6.31 \mathrm{E}-05 \\
{[0.000488]}\end{array}$ & $\begin{array}{l}-0.000555 \\
{[0.000296]}\end{array}$ & c & Duyuru 13 & $\begin{array}{l}0.00017 \\
{[0.001117]}\end{array}$ & $\begin{array}{l}-0.000872 \\
{[0.000529]}\end{array}$ & C & Sad & $\begin{array}{l}0.009645 \\
{[0.005256]}\end{array}$ & $\begin{array}{l}\text { C }-0.006145 \\
{[0.004815]}\end{array}$ & \\
\hline & & & Duyuru 13 & $\begin{array}{l}0.000113 \\
{[0.001129]}\end{array}$ & $\begin{array}{l}-0.000841 \\
{[0.000527]}\end{array}$ & c & $\mathrm{R}^{\mathrm{f} \text { or d }}{ }_{(\mathrm{t}-1)}$ & $\begin{array}{l}-0.01005 \\
{[0.003241]}\end{array}$ & $\begin{array}{l}\text { a }-0.001117 \\
{[0.002654]}\end{array}$ & & Yeni ay & $\begin{array}{l}-0.0002 \\
{[0.000088]}\end{array}$ & $\begin{array}{l}\text { b } 2.41 \mathrm{E}-05 \\
{[0.0000858]}\end{array}$ & \\
\hline & & & $\mathrm{R}_{(\mathrm{t}-1)}^{\mathrm{ford}}$ & $\begin{array}{l}-0.010487^{\mathbf{a}} \\
{[0.003238]}\end{array}$ & $\begin{array}{l}-0.001309 \\
{[0.002635]}\end{array}$ & & SAD & $\begin{array}{l}0.009818 \\
{[0.005088]}\end{array}$ & $\begin{array}{l}\text { b }-0.006583 \\
{[0.004693]}\end{array}$ & & Dolunay & $\begin{array}{l}0.000212 \\
{[0.0000957]}\end{array}$ & $\begin{array}{l}\mathbf{b}-0.0002 \\
{[0.000084]}\end{array}$ & b \\
\hline & & & Sabit & $\begin{array}{l}0.00029 \quad \mathbf{b} \\
{[0.000137]}\end{array}$ & $\begin{array}{l}0.000188 \\
{[0.000123]}\end{array}$ & & Yeni ay & $\begin{array}{l}-0.000171 \\
{[0.0000932]}\end{array}$ & $\begin{array}{l}\text { c } 4.17 \mathrm{E}-05 \\
{[0.000083]}\end{array}$ & & Sabit & $\begin{array}{l}-0.000921 \\
{[0.000606]}\end{array}$ & $\begin{array}{l}0.000906 \\
{[0.000568]}\end{array}$ & c \\
\hline & & & & & & & Dolunay & $\begin{array}{l}0.000199 \\
{[0.0000894]}\end{array}$ & $\begin{array}{l}{ }^{\mathrm{a}}-0.0002 \\
\\
{[0.0000808]}\end{array}$ & b & & & & \\
\hline & & & & & & & Sicaklık & $\begin{array}{l}2.84 \mathrm{E}-05 \\
{[0.000162]}\end{array}$ & $\begin{array}{l}-3.66 \mathrm{E}-05 \\
{[0.000126]}\end{array}$ & & & & & \\
\hline & & & & & & & $\begin{array}{l}\text { Bulutluluk } \\
\text { oranı }\end{array}$ & $\begin{array}{l}2.97 \mathrm{E}-05 \\
{[0.0000161]}\end{array}$ & $\begin{array}{l}{ }^{c}-1.76 \mathrm{E}-05 \\
\\
{[0.0000141]}\end{array}$ & & & & & \\
\hline & & & & & & & Yağmur & $\begin{array}{l}-3.87 \mathrm{E}-05 \\
{[0.0000801]}\end{array}$ & $\begin{array}{l}-5.07 \mathrm{E}-05 \\
{[0.0000668]}\end{array}$ & & & & & \\
\hline & & & & & & & Sabit & $\begin{array}{l}-0.000952 \\
{[0.000588]}\end{array}$ & $\begin{array}{l}0.00108 \\
{[0.000549]}\end{array}$ & W & & & & \\
\hline F-istatistiği & 4.733 & a 6.314 & $\mathrm{a}$ & 3.236 & 4.110 & $\mathrm{a}$ & & 3.334 & a 3.924 & $\mathrm{a}$ & & 8.574 & a 8.989 & a \\
\hline
\end{tabular}




\section{Muhasebe ve Finansman Dergisi}

Düzeltilmiş $\mathrm{R}^{2} 0.031 \quad 0.043$

D.W. istat. $\quad 1.70 \quad 1.70$

$1.70-\frac{10}{20}$

1.74

0.046

1.70

\section{Ekim/2016}

Notlar:

1- Hata terimlerinin değişen varyans ve otokorelasyon sorununa sahip olabilme ihtimaline karşın, analizlerde, Newey-West tahmincisi kullanılmıştır. İlgili katsayı tahminlerinin altında, köşeli parantez içinde verilen değerler, otokorelasyon ve değişen varyansla tutarlı hale getirilmiş standart hatalardır (Newey West robust standart errors).

2- ${ }^{\mathrm{a}}$, ve ${ }^{\mathrm{c}}$; katsayı tahminlerinin sırasıyla $\% 1, \% 5$ ve $\% 10$ anlamlılık seviyesinde istatistiksel olarak anlamlı olduğunu ifade etmek için kullanılmıştır.

3- Bu tabloda alandan tasarruf sağlanması amacıyla her bir regresyon denklemi için salt istatistiksel olarak anlamlı bulunan değişkenlere yer verilmiştir. 


\section{SONUÇ}

Davranışsal finans alanında yer alan çalışmalarda yatırımcı ruh hali, ruh haline etki eden dolunay, hava sıcaklığı, hava kirliliği gibi birçok dışsal faktörle temsil edilmektedir. $\mathrm{Bu}$ çalışmada da benzer şekilde, önceki günde kayıp yaşayan yatırımcıların negatif ruh haline sahip oldukları varsayılmaktadır. Çünkü Thaler ve Johnson'a (1990) göre, daha öncesinde yaşanan kayıplar, bireylerin ruh halini negatif yönde etkilemektedir. Buna göre önceki gün kayıp yaşayan yatırımcının bugünkü ruh hali, negatiftir.

$\mathrm{Bu}$ çalışmanın temel amacı, önceki kayıplar ile temsil edilen negatif ruh halinin yerli ve yabancı yatırımcıların hisse senedi talepleri üzerindeki etkilerini incelemektir.

Belirtilen amaç doğrultusunda çalışmada, Kasım 2005 - Nisan 2015 dönemi aralığında yerli ve yabancı yatırımcıların portföylerinde bulunan günlük hisse miktarları ile bu portföylerin Pazar değerleri, veri olarak kullanılmıştır. Ayrıca iyi bilinen takvimsel anomalileri, makroekonomik faktörleri ve alternatif ruh hali vekil değişkenlerini kontrol altına almak ve böylece analiz sonuçlarını robust kılmak amacıyla daha birçok veri de analizlere dâhil edilmiştir. Çalışmanın analizleri, OLS regresyon analizi kullanılarak gerçekleştirilmiştir.

Çalışma sonucunda; (i) negatif ruh haline sahip yerli yatırımcıların hisse taleplerini artırdığı, (ii) buna karşın negatif ruh haline sahip yabancı yatırımcıların ise hisse taleplerini azalttığı, (iii) fakat öncesinde yaşanan kaybın sonraki günde telafi edilme olasılığı arttıkça yabancı yatırımcıların da hisse taleplerini artırdığı tespit edilmiştir. İlginç bir sonuç ise şudur; yerli yatırımcılar, öncesinde yaşanan kaybın sonraki günde telafi edilme olasılığına anlamlı bir şekilde tepki vermemektedirler.

Çalışma oldukça ilginç bulgulara sahiptir. Öncelikle negatif ruh halindeki yerli ve yabancı yatırımcılarda farklı davranışlar gözlemlenmektedir. Çok genel bir ifadeyle yerli yatırımcılar, riski daha fazla sevmektedirler. Bunun nedeni kültürel farklılıklar olabileceği gibi yerli yatırımcıların, daha iyi tanıdıkları bir piyasada yatırım yapmanın avantaj sağlayacağı düşüncesiyle hisse alımlarına ağırlık vermeleri de olabilir (yerel hisse tercihi etkisi, home-bias). Sebebi ne olursa olsun bu sonuç, Türkiye borsası özelinde yapılacak sonraki çalışmalarda, özellikle yerli ve yabancı yatırımcıların ayrı ayrı analiz edilmesi gerektiğinin önemli olduğunu vurgulamaktadır. Yerli-yabancı ayrımına gidilmeksizin Türkiye borsasında yapılacak çalışmalar, negatif (pozitif) ruh halinin hisse fiyatlarını yani taleplerini azalttı̆̆ı (artırdığı) sonucuna ulaşabilir; bilinmektedir ki Türkiye borsasındaki hareketlerin belirleyicisi konumunda olan yatırımcı grubu, yabancıdır ve negatif (pozitif) ruh halindeki yabancı yatırımcı, hisse taleplerini azaltmaktadır (artmaktadır).

Farklı yöntemleri ya da farklı ruh hali vekil değişkenlerini kullanarak yapılacak sonraki çalışmaların, son 10 yılda yoğun ilgi gören ruh hali-yatırımcı davranışı ile ilişkili literatüre katkı sağlayabilecekleri düşünülmektedir. 


\section{KAYNAKLAR}

Bower, Gordon H. (1981), "Mood and memory”, American psychologist, Vol. 36, No. 2, pp. 129-148.

Berument, M. Hakan- Ceylan, Nildağ Başak (2012), "Effects of soccer on stock markets: The return-volatility relationship”, The Social Science Journal, Vol.49, No. 3, pp. 368374.

B1ałkowsk1, Jędrzej- Etebar1, Ahmad- Wisnıewsk1, Tomasz Piotr (2012), "Fast profits: Investor sentiment and stock returns during Ramadan”, Journal of Banking \& Finance, Vol. 36, No. 3, pp. 835-845.

Bozkurt, İbrahim (2015), "Investigation of the Effects of the Moon on Stock Returns: An Empirical Application on ISE”, İktisat İşletme ve Finans, Vol. 30, No. 352, pp. 55-78.

Bradley, Teresa (2007). Essential Statistics for Economics, Business and Management, John Wiley \& Sons, Ltd., England.

Bruyneel, Sabrina- Dewitte, Siegfried- Franses, Philip H.- Dekimpe, Marnik G. (2009), “I felt low and my purse feels light: Depleting mood regulation attempts affect risk decision making”, Journal of Behavioral Decision Making, Vol. 22, pp. 153-170.

Cao, Melanie- Wei, Jason (2005), “Stock market returns: A note on temperature anomaly”, Journal of Banking \& Finance, Vol. 29, No. 6, 1559-1573.

Conte, Anna- Levati, M. Vittoria- Nardi, Chiara (2013), The role of emotions on risk preferences: An experimental analysis (No. 2013-046). Jena Economic Research Papers.

http://www.tuik.gov.tr/takvim/tkvim.zul\#tb2 14.06.2015

http://www.tcmb.gov.tr/ , 14.06.2015

http://www.borsaistanbul.com 14.06.2015

http://www.eia.gov/, 14.06.2015

Hirshleifer, David- Shumway, Tyler (2003), “Good day sunshine: Stock returns and the weather”, The Journal of Finance, Vol. 58, No. 3, pp. 1009-1032.

Ibrahim, Mansor H.- Yusoff, Sulaiman W. (2001), "Macroeconomic variables, exchange rate and stock price: A Malaysian perspective”, International Journal of Economics, Management and Accounting, Vol. 9, No. 2, pp. 141-163.

Iglewicz, Boris- Hoaglin, David (1993). How to detect and handle outliers, ASQC Quality Press, Milwaukee.

Isen, Alice M.- Geva, Nehemia (1987), “The influence of positive affect on acceptable level of risk: The person with a large canoe has a large worry”, Organizational Behavior and Human Decision Processes, Vol. 39, No. 2, pp. 145-154. 
Isen, Alice M.- Shalker, Thomas E.- Clark, Margaret- Karp, Lynn (1978), “Affect, accessibility of material in memory, and behavior: A cognitive loop?”, Journal of personality and social psychology, Vol. 36, No. 1, pp. 1-12.

Johnson, Eric J.- Tversky, Amos (1983), “Affect, generalization, and the perception of risk”, Journal of personality and social psychology, Vol. 45, No. 1, pp. 20-31.

Kamstra, Mark J.- Kramer, Lisa A.- Levi, Maurice D. (2003), "Winter blues: A SAD stock market cycle”, American Economic Review, Vol. 93, No. 1, pp. 324-343.

Kavanagh, David J.- Bower, Gordon H. (1985), "Mood and self-efficacy: Impact of joy and sadness on perceived capabilities”, Cognitive Therapy and Research, Vol. 9, No. 5, pp. 507-525.

Leith, Karen Pezza- Baumeister, Roy F. (1996), "Why do bad moods increase self-defeating behavior? Emotion, risk taking and self-regulation”, Journal of Personality and Social Psychology, Vol. 71, pp. 1250-1267.

Lepori, Gabriele M. (2010), "Positive mood, risk attitudes, and investment decisions: Field evidence from comedy movie attendance in the US”, Available at SSRN: http://ssrn.com/abstract=1690476 or http://dx.doi.org/10.2139/ssrn.1690476

Levy, Tamir- Yagil, Joseph (2011), “Air pollution and stock returns in the US”, Journal of Economic Psychology, Vol. 32, No. 3, pp. 374-383.

Lin, Chien H.- Yen, Hsiuju R.- Chuang, Shin Chien (2007), “The effects of emotion and need for cognition on consumer choice involving risk", Journal of Business and Psychology, Vol. 22, No. 1, pp. 65-78.

Loewenstein, George F.- Weber, Elke U.- Hsee, Christopher K.- Welch, Ned (2001), "Risk As Feelings”, Psychological Bulletin, Vol. 127, No. 2, March, pp. 267-286.

Loewenstein, George (2000), "Emotions in economic theory and economic behavior”, American economic review, Vol. 90, No. 2, pp. 426-432.

Mayer, John D.- Gaschke, Yvonne N.- Braverman, Debra L.- Evans, Temperance W. (1992), "Mood-congruent judgment is a general effect”, Journal of Personality and Social Psychology, Vol. 63, No. 1, pp. 119-132.

Mick, David Glen- DeMoss, Michelle (1990), "Self-gifts: Phenomenological insights from four contexts”, Journal of Consumer Research, pp. 322-332.

Mittal, Vikas- Ross, William T. (1998), “The impact of positive and negative affect and issue framing on issue interpretation and risk taking”, Organizational Behavior and Human Decision Processes, Vol. 76, No. 3, pp. 298-324.

Raghunathan, Rajagopal- Pham, Michel Tuan (1999), “All negative moods are not equal: Motivational influences of anxiety and sadness on decision making”, Organizational Behavior and Human Decision Processes, Vol. 79, No. 1, pp. 56-77. 
Romer, Paul M. (2000), “Thinking and feeling”, American Economic Review, Vol. 90, No.2, pp. 439-443.

Rousseeuw, Peter J.- Leroy, Annick M. (1987), Robust regression and outlier detection, John Wiley \& Sons, New York.

Saunders, Edward M. (1993), "Stock prices and Wall Street weather”, The American Economic Review, Vol. 83, No. 5, pp. 1337-1345.

Schwarz, Norbert- Clore, Gerald L. (1983), “Mood, misattribution, and judgments of wellbeing: Informative and directive functions of affective states”, Journal of personality and social psychology, Vol. 45, No. 3, pp. 513-523.

Schwarz, Norbert- Clore, Gerald L. (1988), How do I feel about it? The informative function of affective states. In K. Fiedler and J. Forgas (Eds.), Affect, cognition, and social behavior (pp.44-62). Göttigen, Federal Republic of Germany: Hogrefe.

Thaler, Richard H.- Johnson, Eric J. (1990), “Gambling with the house money and trying to break even: The effects of prior outcomes on risky choice”, Management science, Vol. 36, No. 6, pp. 643-660.

Wright, William F.- Bower, Gordon H. (1992), "Mood effects on subjective probability assessment”, Organizational behavior and human decision processes, Vol. 52, No. 2, pp. 276-291.

Yuen, Kenneth S.- Lee, Tatia M. (2003), "Could mood state affect risk-taking decisions?”, Journal of affective disorders, Vol. 75, No. 1, pp. 11-18.

Zillmann, Dolf (1988), “Mood management through communication choices”, American Behavioral Scientist, Vol. 31, pp. 327-340. 
